\title{
Linear Shrinkage Behaviour of Compacted Loam Masonry Blocks
}

\author{
NAWAB ALI LAKHO*, MUHAMMAD AUCHAR ZARDARI*, AND ASHFAQUE AHMED PATHAN** \\ RECEIVED ON 29.02.2016 ACCEPTED ON 22.11.2016
}

\begin{abstract}
Walls of wet loam, used in earthen houses, generally experience more shrinkage which results in cracks and less compressive strength. This paper presents a technique of producing loam masonry blocks that are compacted in drained state during casting process in order to minimize shrinkage. For this purpose, loam masonry blocks were cast and compacted at a pressure of $6 \mathrm{MPa}$ and then dried in shade by covering them in plastic sheet. The results show that linear shrinkage of $2 \%$ occurred which is smaller when compared to un-compacted wet loam walls. This implies that the loam masonry blocks compacted in drained state is expected to perform better than un-compacted wet loam walls.
\end{abstract}

Key Words: Compaction, Shrinkage, Wall panels, Loam, Clay, Drained State.

\section{INTRODUCTION}

$\int$

oam has been used as a material of construction for low cost houses since ancient times till today [1-3]. Loam consists of about $40 \%$ sand, $40 \%$ silt and $20 \%$ clay by weight. The use of unfired bricks is found to be about 10000 years in different parts of the world such as Mesopotamia and China [4]. In Egypt, about 3200 years old arched roof storage rooms, made with adobes are still surviving [4]. Wet loam walls are also constructed to reduce cost of labour during casting process of the material and to produce relatively stronger walls in comparison to the adobe masonry. Natural loam is economical both in quarrying and as material of construction. The cost for quarrying, transportation, handling and processing of loam is generally $5 \%$ of that of concrete [4]. In addition to this, the use of loam is environmental friendly as compared to reinforced cement concrete, and baked clay bricks. This is because, emission of carbon dioxide occurs during manufacturing process of cement, and firing of bricks which may adversely affect the environment [4-12].

When loam is used for construction of buildings, it is described with different names such as: (i) adobes or mud bricks (molded un-fired bricks), (ii) stabilized compressed earth blocks (loam stabilized with cementing agent such as lime or cement and compacted after mixing with water), (iii) rammed earth (loam mixed with stabilizer, aggregates, organic fiber such as straw etc. and compacted at site to form a wall [4].

$\begin{array}{ll}* & \text { Department of Civil Engineering, Quaid-e-Awam University of Engineering, Science \& Technology, Nawabshah. } \\ * * & \text { Department of Civil Engineering, Mehran University of Engineering \& Technology, Jamshoro. }\end{array}$

Mehran University Research Journal of Engineering \& Technology, Volume 36, No. 2, April, 2017 [p-ISSN: 0254-7821, e-ISSN: 2413-7219] 
Wet loam construction generally experiences $3-15 \%$ shrinkage and as a result cracks develop [4, 13-23]. These cracks can destroy aesthetic view and cause weak section at place of cracks in walls. The drawbacks such as: weak bond between masonry units, cost of labour and drying cracks can be reduced if large moist loam blocks are compacted in drained state.

For construction of loam masonry walls, loam soil is mixed with water. During drying, water evaporates and the soil particles become closer to each other, resulting in shrinkage. This implies that shrinkage is directly related to the quantity of water that is added during mixing process of the soil. If the loam wall is thicker, more time will be required for drying because of the slow evaporation of moisture. If the water content of the soil is reduced to the shrinkage limit, it is expected that shrinkage will be significantly controlled. But, for construction of loam masonry walls, more water content is required for easy moulding and workability. In addition, it is to be noted that slow and even drying of loam walls is necessary in order to avoid warping, cracking or deformation [24]. In order to resolve the problem of shrinkage in loam masonry walls, a new technique of drained state compaction of loam masonry blocks is introduced in this paper.

\section{MATERIALS AND METHOD}

\subsection{Casting of Loam Masonry Wall Units}

Loam was quarried, in the vicinity of Nawabshah city, at a depth of more than $1200 \mathrm{~mm}$ to avoid mixing of roots of the plants and debris of aggregates in it. The quarry was dried properly in the sun and pulverized. Sieve analysis was performed and it was found that the quarry contained more clay content, about $40 \%$ of fine sand, by weight, was mixed in it in order to reduce drying shrinkage, increase compressive strength. The mixing of $40 \%$ of sand is based on the results of a preliminary study that was conducted to find out the optimum quantity of sand to be mixed with clay. Quantity of water mixed was $22 \%$ of the mixture. The natural moisture content, liquid limit, and plastic limit of the loam were, 12,40 and $20 \%$, respectively.

The mixture was placed in equal layers in the steel mould (Fig. 1) of the Mechanized System (Fig. 2) to produce wall masonry units. The clay wall panels were of the size 150 mm x300 mm x1980 mm (width, depth, and length, respectively). These moist clay wall masonry units were wrapped in propylene fabric sheet. These wall masonry units were dried for a period of 150 days at room temperature. After casting of the wall masonry units (Fig. 3), they were covered with plastic sheet and dried in shade (Fig. 4).

Five lam masonry blocks were tested to determine average rate of linear shrinkage and rate of evaporation of moisture.

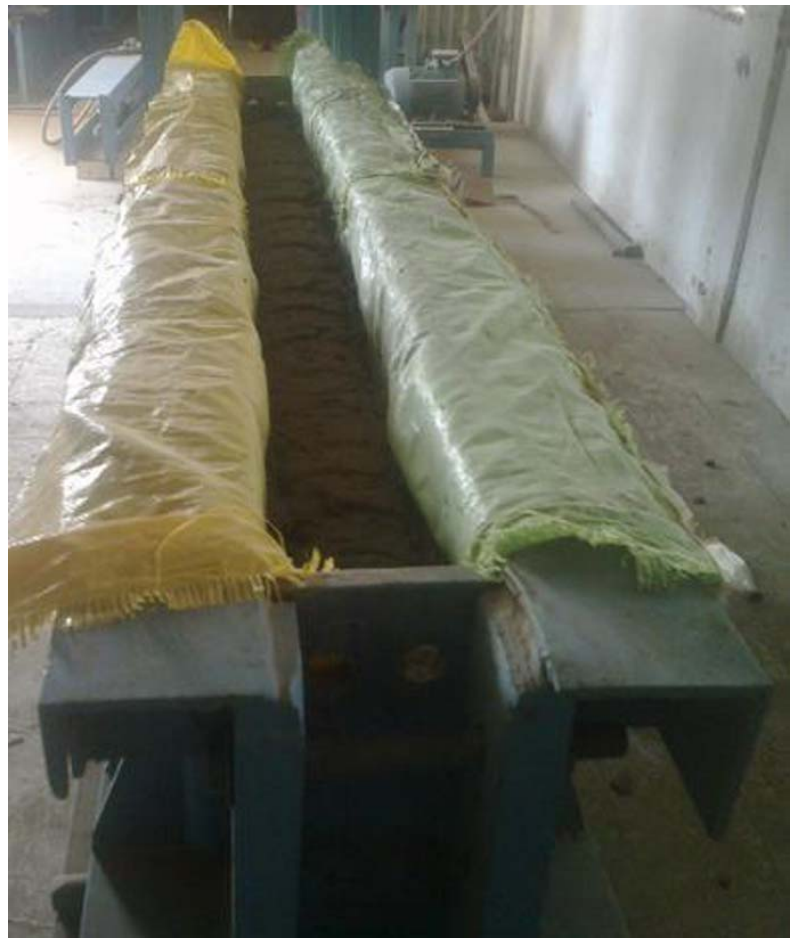

FIG. 1. WALL UNIT BEING CAST IN MOULD 


\section{RESULTS AND DISCUSSION}

\subsection{Linear Shrinkage}

Loam wall masonry units were cast and compacted at 6 $\mathrm{MPa}$ and were dried being covered in plastic sheet in shade. When this loam mixture was compacted at the intensity of compaction of $6 \mathrm{MPa}$, maximum possible dry density was achieved. The behaviour of linear shrinkage of the representative wall masonry unit is shown in Fig. 5. The results show that linear shrinkage of $2.2 \%$ occurred in 150 days. This amount of shrinkage is comparatively smaller than that of un-compacted clay loam which generally ranges from.3-12\% [4]. This is because in moist un-compacted clay, the voids are filled with water and soil particles are separated away by the presence of water molecules between them. On increasing moisture in clay it swells and on reduction of

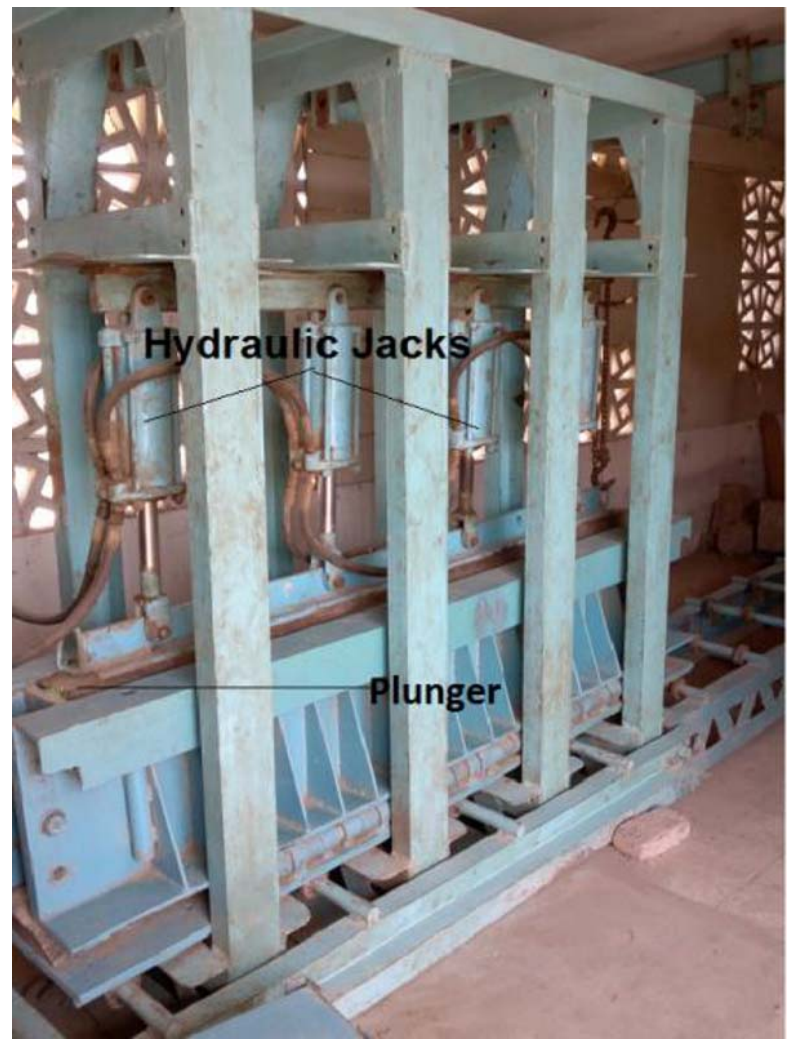

FIG. 2. MECHANIZED SYSTEM FOR CASTING AND COMPACTING OF LOAM MASONRY WALL UNITS moisture by evaporation shrinkage occurs in it [4]. In this study, a technique was utilized to compress the clay wall panels by wrapping them with the porous propylene fabric sheet creating drained state during compaction. The extra moisture was pressurized to ooze out of the body of moist clay and the voids were reduced with compaction through compression causing the reduction of the volume and increase in density.

Due to more density, the compacted loam masonry units are expected to show better performance in their service life as compared to the walls constructed of wet loam. It is to be noted that compaction of loam masonry units during casting process plays an important role in reducing shrinkage cracks and increasing the density. If such loam masonry units are fired, are expected to give higher compressive strength.

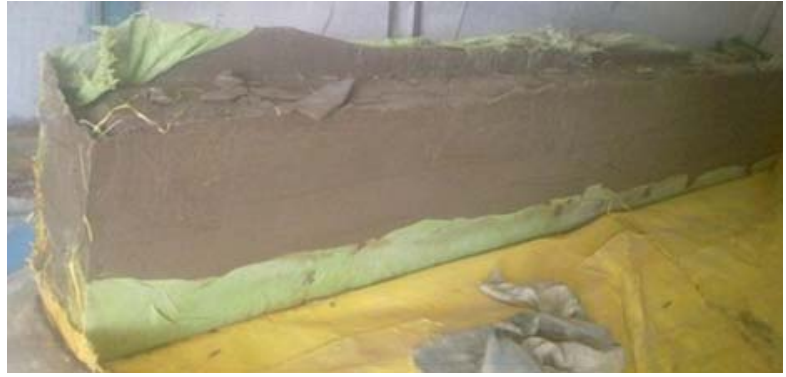

FIG. 3. A VIEW OF WALL MASONRY BLOCK IMMEDIATELY AFTER CASTING

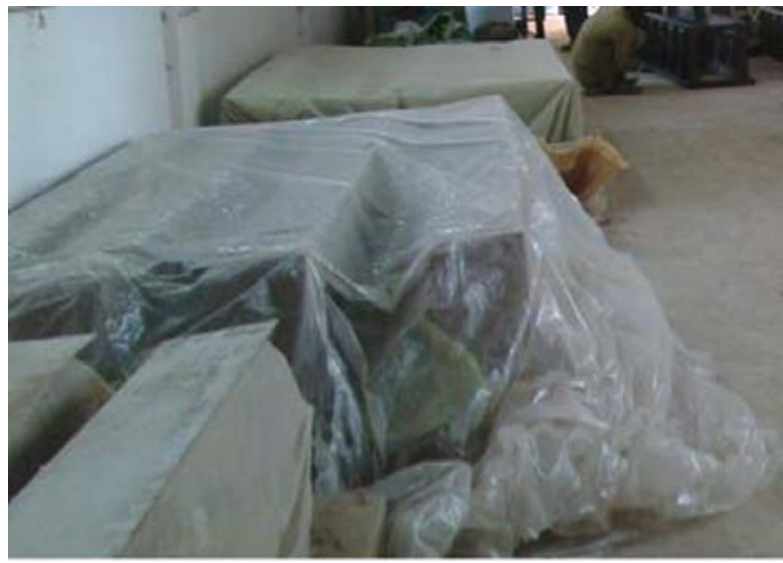

FIG. 4. LOAM MASONRY WALL UNITS COVERED WITH PLASTIC SHEET ARE BEING DRIED IN SHADE

Mehran University Research Journal of Engineering \& Technology, Volume 36, No. 2, April, 2017 [p-ISSN: 0254-7821, e-ISSN: 2413-7219] 
It is pertinent to mention here that the loam masonry units were dried in shade and the drying process took about 150 days in order to get crack-free wall masonry units. This is too much time for drying process. Therefore, it is necessary to reduce drying time of the loam masonry units. For this purpose, some admixtures like organic fiber such as chopped straw, chaff, cattail powder, and gunny bag fiber can be added. With the addition of such admixtures, the time of drying of loam wall masonry units could be reduced. But on other hand, the addition of fibers may decrease the density of the loam wall masonry units and on firing it may produce pores due to burning of organic fiber. Thus it will be interesting to investigate the effect of different admixtures on the rate of drying of moist loam wall masonry units, which do not affect the strength and durability even after baking.

\subsection{Rate of Evaporation of Moisture}

Fig. 6 shows the rate of evaporation of moisture from a compacted loam wall masonry units. It can be seen that $11.8 \%$ of water was evaporated from the moist loam wall masonry units. The evaporation process was almost steady though it went some abrupt during middle and later periods (Fig. 7). The main intention of this study was to decrease the possibility of drying shrinkage cracks by reducing the rate of evaporation to a minimum percentage by covering the moist loam wall masonry units with plastic sheet. It is to be noted that the loam wall masonry units were dried in the covered hall during summer period, i.e. from March to August months during which the outside temperature remains high between 35$50^{\circ} \mathrm{C}$. On the other hand, if the loam wall masonry units had been dried during winter period, they might have taken more time for drying. This necessitates to investigate the possible use of admixtures to reduce drying time.

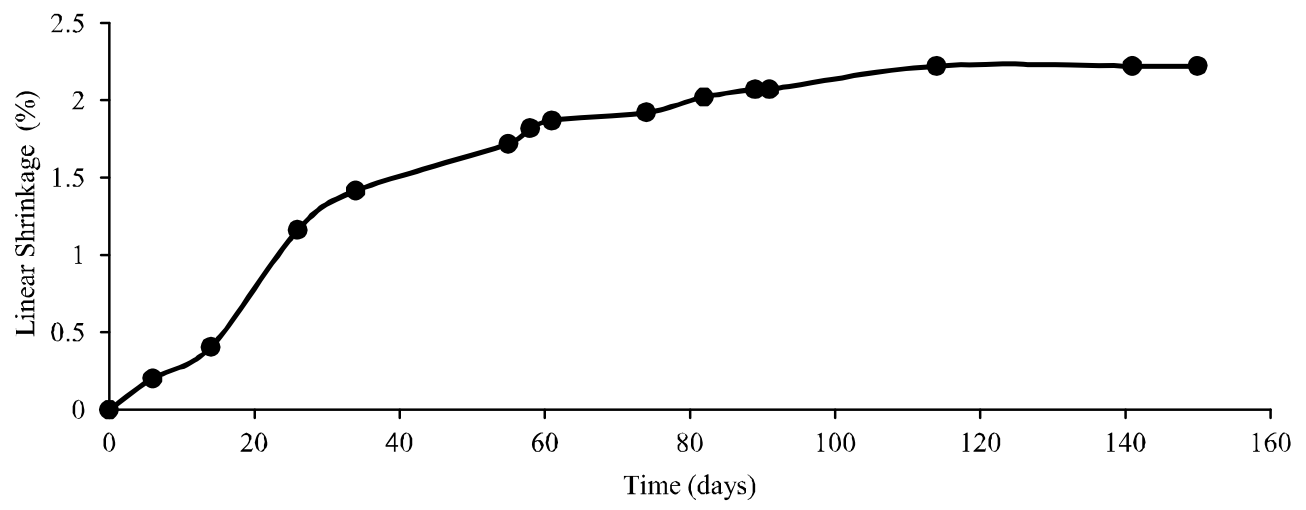

FIG. 5. LINEAR SHRINKAGE BEHAVIOUR OF THE COMPACTED LOAM WALL MASONRY UNIT

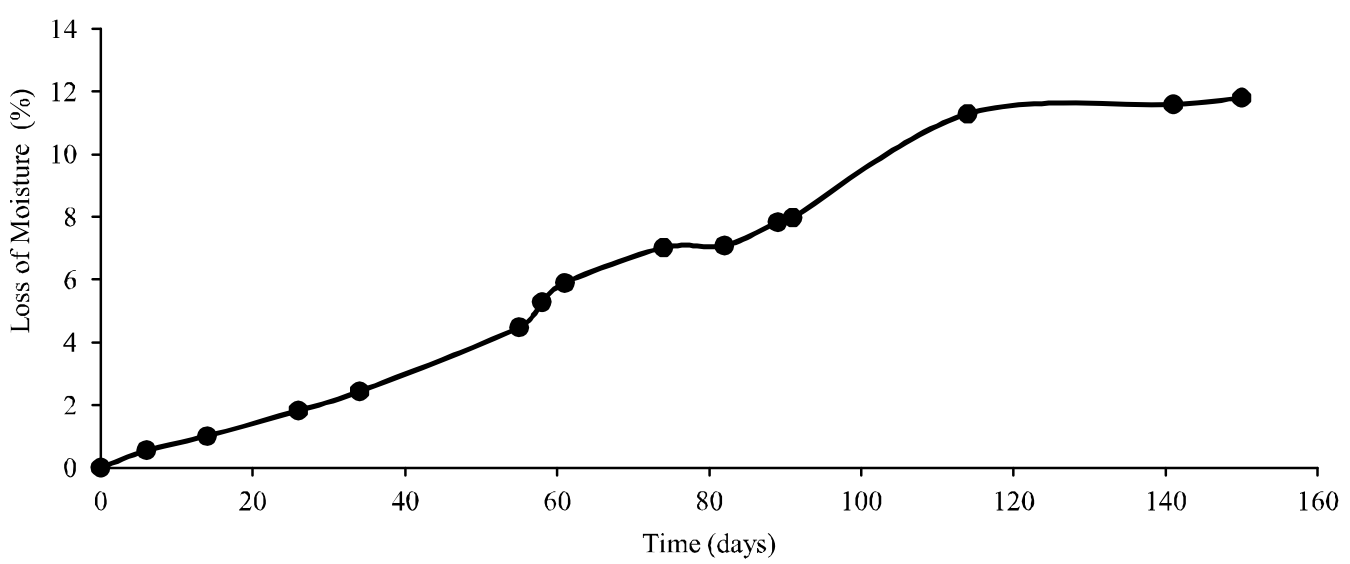

FIG. 6. RATE OF EVAPORATION OF MOISTURE FROM LOAM WALL MASONRY UNITS

Mehran University Research Journal of Engineering \& Technology, Volume 36, No. 2, April, 2017 [p-ISSN: 0254-7821, e-ISSN: 2413-7219] 


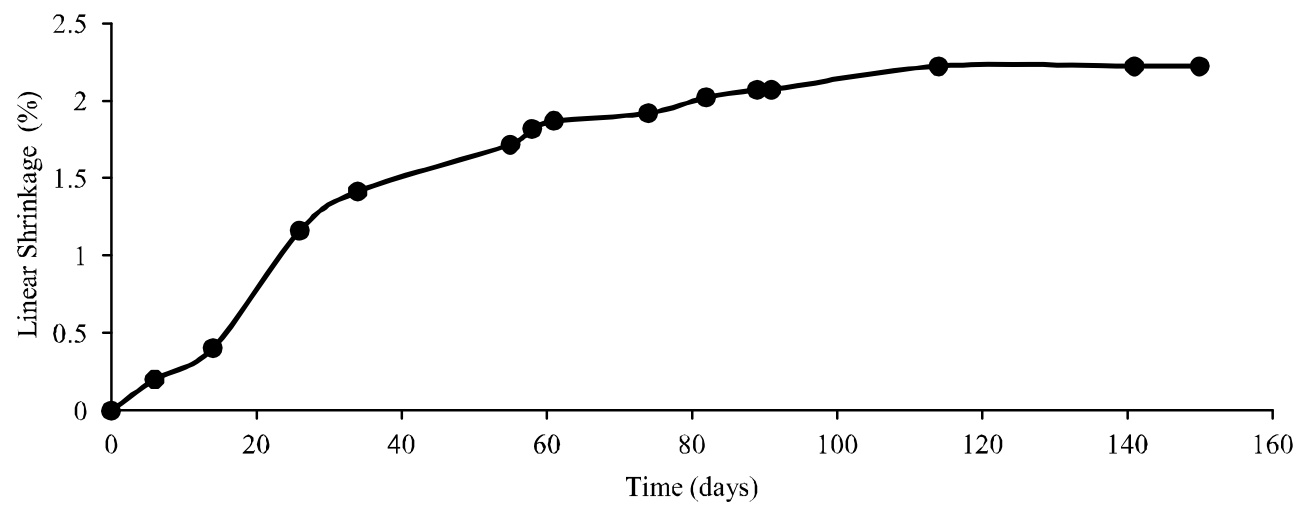

FIG. 7. LINEAR SHRINKAGE BEHAVIOUR OF THE COMPACTED LOAM WALL MASONRY UNIT

\section{CONCLUSIONS}

In this paper, a technique of drained state compaction to reduce shrinkage of compacted loam masonry blocks was presented. The main conclusions drawn from this study are:

(i) The technique of drained state compaction of casting loam masonry blocks was found to be effective in reducing linear shrinkage up to $2.2 \%$.

(ii) By allowing drainage during compaction, almost half of the water added during mixing was expelled. The lesser the amount of water, lower was rate of shrinkage.

(iii) These compacted loam blocks took about 21 weeks to dry which is not desirable. Thus, some treatments are to be investigated to reduce the time of drying without any shrinkage cracks.

\section{ACKNOWLEDGEMENT}

The authors would like to thank Quaid-e-Awam University of Engineering Science and Technology, Nawabshah, for providing access to the Structural Engineering Laboratory to conduct the tests mentioned in this study.

\section{REFERENCES}

[1] Rajoviæ, G., and Jelisavka B., "Characteristics of Housing in Rural Villages: The Case Northeastern Montenegro", International Letters of Social and Humanistic Sciences, Volume 6, pp. 24-35, 2013.

[2] Pacheco-Torgal, F., and Jalali, S., "Earth Construction: Lessons from the Past for Future Coefficient Construction", Construction and Building Materials, Volume 29, pp. 512-519, 2012.

[3] Persson, S. "Indigenous Materials in Modern Buildings: For Low Energy Houses in West Africa", M.Sc. Thesis, Uppsala University, Sweden, 2014.

[4] Minke, G., "Building with Earth: Design and Technology of a Sustainable Architecture", Walter de Gruyter, 2012.

[5] Makinde, O.O., "Ecological and Sustainability Issues In Earth Construction", IOSR Journal of Environmental Science, Toxicology \& Food Technology, Volume 1, No. 4, pp. 2319-2402, 2012.

[6] Birznieks, L., "Designing and Building with Compressed earth", Doctoral Dissertation, Delft University of Technology, 2013.

[7] Kvarnström, D., "Construction of Low Cost Houses in Informal Settlements", M.Sc. Thesis, Chalmers University, Göteborg, Sweden, 2014.

[8] Swan, A.J., Rteil, A., and Lovegrove, G., "Sustainable Earthen and Strawbale Construction in North American Buildings: Codes and Practice”, Journal of Materials in Civil Engineering, Volume 23, No. 6, pp. 866-872, 2011. 
[9] Nunan, J., "The Complete Guide to Alternative Home Building Materials and Methods: Including Sod, Compressed Earth, Plaster, Straw, Beer Cans, Bottles, Cordwood, and Many other Low Cost Materials", Atlantic Publishing Company, 2010.

[10] Zami, M.S., and Lee, A., "Economic Benefits of Contemporary Earth Construction in Low-Cost Urban Housing-State-of-the-Art review", Journal of Building Appraisal, Volume 5, No. 3, pp. 259-271, 2010.

[11] Alagbe, O.A., "Enhancing Sustainable Housing Development in Nigeria using Compressed Stabilized Laterite Bricks", Journal of Sustainable Development and Environmental Protection, Volume 1, No. 3 , pp. 51-59, 2011.

[12] Williams, C., Goodhew, S., Griffiths, R., and Watson, L., "The Feasibility of Earth Block Masonry for Building Sustainable Walling in the United Kingdom", Journal of Building Appraisal, Volume 6, No. 2, pp. 99-108, 2010.

[13] Keefe, L., "Earth Building: Methods and Materials, Repair and Conservation", Routledge, 2012.

[14] Burroughs, S., "Recommendations for the Selection, Stabilization, and Compaction of Soil for Rammed Earth Wall Construction", Journal of Green Building, Volume 5, No. 1, pp. 101-114, 2010.

[15] Melià, P., Ruggieri, G., Sabbadini, S., and Dotelli, G., "Environmental Impacts of Natural and Conventional Building Materials: A Case Study on Earth Plasters", Journal of Cleaner Production, Volume 80, pp. 179-186, 2014.
Zhao, D.J., Zhang, Y., and Lu, J.L., "Research on Construction of Rammed Earth Buildings", Advanced Materials Research, Volume 243, pp. 934-937, 2011.

[17] Simenson, E.W., "Rammed Earth: Fiber-Reinforced, Cement-Stabilized", Doctoral Dissertation, University of Colorado, USA, 2013

[18] Zhang, P.C., Luo, K., and Liao, W.B., "Study on the Material and the Structure of Earth Building in Fujian", Advanced Materials Research, Volume 368, pp. 3567-3570, 2012.

[19] Quagliarini, E., and Lenci, S., "The Influence of Natural Stabilizers and Natural Fibres on the Mechanical Properties of Ancient Roman Adobe Bricks", Journal of Cultural Heritage, Volume 11, No. 3, pp. 309-314, 2010.

[20] Montana, G., Randazzo, L., and Sabbadini, S., "GeoMaterials in Green Building Practices: Comparative Characterization of Commercially Available Clay-Based Plasters", Environmental Earth Sciences, Volume 71, No. 2, pp. 931-945, 2014.

[21] Niroumand, H., Zain, M.F.M., and Alhosseni, S.N., "Earth Building Materials, Production, and Construction Techniques", IGI Global, 2013.

[22] Liuzzi, S., and Stefanizzi, P., "Soil Based Building Materials for Energy Efficiency”, Key Engineering Materials, Volume 632, pp. 15-38, 2014

[23] Galán-Marín, C., Rivera-Gómez, C., and Petric, J., "ClayBased Composite Stabilized with Natural Polymer and Fibre", Construction and Building Materials, Volume 24, No. 8, pp. 1462-1468, 2010.

[24] Rhodes, D., and Hopper, R., "Clay and Glazes for the Potter”, Krause Publications Craft, 2000. 